\title{
Student Achievement Awards / Prix d'excellence étudiant CLA/ACL 2017, Université Ryerson
}

\section{Best 20-minute presentations / Meilleures communications de 20 minutes}

Nicole Hildebrand-Edgar (York University): "I don't know in Toronto and Victoria: Comparing analyses of discourse variation"

Nicole Hildebrandt-Edgar showed a great deal of sophistication in the quality of her research and methodology as well as her professionalism and presence. She covered complex material thoroughly and effectively. Her project revealed the complex use of this common expression, and bears on theoretically fruitful and under-explored concepts such as the relation of phonetic reduction to pragmatic, discursive and social meaning.

\section{$* * *$}

Nicole Hildebrandt-Edgar a fait preuve d'un haut degré de subtilité pour ce qui est la qualité et la méthodologie de sa recherche, ainsi que sa présence et son professionnalisme. Elle a présenté des données complexes avec rigueur et efficacité. Son projet dévoile l'usage complexe qui est fait de cette expression commune et porte sur des concepts peu explorés, mais ayant une grande importance théorique, tels que la relation entre la réduction phonétique et le sens pragmatique, discursif et social.

\section{Julianne Doner (University of Toronto): "Predicate-sensitive EPP"}

Doner's proposal - to look at the extended projection principle from the angle of predicates rather than arguments and nominal categories - was promising and very insightful. Particularly impressive was her ability to engage with the very abstract theoretical literature, her grasp of the problem and her innovative solution. She demonstrated excellent command of both theory and data, and offered an original, crosslinguistic view of predicate-fronting phenomena.

\section{***}

La proposition de Doner - d'aborder le principe de projection étendue sous l'angle des prédicats, plutôt que des arguments et des catégories nominales - est à la fois perspicace et prometteuse. Particulièrement impressionnante ont été sa maîtrise des ouvrages théoriques très abstraits, sa capacité de cerner la problématique, et sa solution innovatrice. Elle a fait preuve d'une excellente maitrise de la théorie et des données linguistiques et a offert une vue originale, interlinguistique, du déplacement des prédicats. 


\section{Best 10-minute presentation / Meilleure communication de 10 minutes}

Virgilio Partida Peñalva (University of Toronto): "Stripping in Spanish: Focalized PP remnants"

Partida Peñalva gave a clear, confident overview of stripping and pseudostripping in Spanish, which was impressively thorough and yet concise, especially given the complexity of the data balanced with the time constraints of a short talk. His proposal was carefully laid out and fully supported by the data. He handled questions very well, and clearly had mastered the literature on the topic.

Partida Peñalva a fait un survol clair et convaincant des fragments unaires en espagnol; sa présentation était à la fois rigoureuse et succincte, malgré la complexité des données et les contraintes de temps. Sa proposition a été soigneusement formulée et bien étayée par les données. Il a bien géré la période des questions et avait clairement une excellente connaissance de la littérature sur le sujet.

\section{Meilleure affiche / Best poster}

Angélica Hernández Constantin (Western University): "Différences régionales dans l'utilisation du verbe impersonnel haber de l'espagnol: Les Caraïbes contre l'Amérique Latine continentale"

L'affiche de Hernández Constantin se distinguait par la limpidité de la présentation des données de son propre corpus portant sur le contraste dans l'usage de haber dans les constructions impersonnelles entre les hispanophones des Caraïbes et ceux de l'Amérique Latine. Ses réponses détaillées et pointues ont bien démontré son expertise, et sa présentation en français et en espagnol a été captivante.

$$
* * *
$$

Hernández Constantin's poster was characterized by the crystal clarity of the presentation of a data set from a corpus she created herself, focusing on Caribbean versus Latin American Spanish speakers' use of haber in impersonal constructions. Her insightful, detailed responses to questions demonstrated her mastery of the topic, and her French and Spanish presentations were very engaging. 